ARTICLE

DOI: $10.1038 / s 41467-018-05638-y$

\title{
One-pot aminobenzylation of aldehydes with toluenes
}

Zhiting Wang ${ }^{1}$, Zhipeng Zheng ${ }^{2}$, Xinyu $\mathrm{Xu}^{1}$, Jianyou Mao (1) ${ }^{1}$ \& Patrick J. Walsh (1) ${ }^{1,2}$

Amines are fundamental motifs in bioactive natural products and pharmaceuticals. Using simple toluene derivatives, a one-pot aminobenzylation of aldehydes is introduced that provides rapid access to amines. Simply combining benzaldehydes, toluenes, $\mathrm{NaN}\left(\mathrm{SiMe}_{3}\right)_{2}$, and additive $\mathrm{Cs}\left(\mathrm{O}_{2} \mathrm{CCF}_{3}\right)$ (0.35 equiv.) generates a diverse array of 1,2-diarylethylamine derivatives (36 examples, 56-98\% yield). Furthermore, suitably functionalized 1,2-diarylethylamines were transformed into 2-aryl-substituted indoline derivatives via Buchwald-Hartwig amination. It is proposed that the successful deprotonation of toluene by $\mathrm{MN}\left(\mathrm{SiMe}_{3}\right)_{2}$ is facilitated by cation- $\pi$ interactions between the arene and the group $(\mathrm{I})$ cation that acidify the benzylic C-Hs.

\footnotetext{
${ }^{1}$ Institute of Advanced Synthesis, School of Chemistry and Molecular Engineering, Jiangsu National Synergetic Innovation Center for Advanced Materials, Nanjing Tech University, 30 South Puzhu Road, 211816 Nanjing, China. ${ }^{2}$ Roy and Diana Vagelos Laboratories, Penn/Merck Laboratory for High-Throughput Experimentation, Department of Chemistry, University of Pennsylvania, 231 South 34th Street, Philadelphia, PA 19104, USA. Correspondence and requests for materials should be addressed to J.M. (email: ias_jymao@njtech.edu.cn) or to P.J.W. (email: pwalsh@sas.upenn.edu)
} 
$\mathrm{T}$ oluene and xylenes are large volume, inexpensive commodity chemicals commonly used as solvents on industrial scale. As such, there are no better feedstocks for the preparation of more elaborate, high-value organic molecules with applications in pharmaceutical sciences, agrochemicals, and materials chemistry ${ }^{1-3}$. To fully exploit these feedstocks, efficient and economical methods for the selective functionalization of the benzylic $\mathrm{C}-\mathrm{Hs}$ are required. Recent advances along these lines have been considerable, although many rely on highly reactive stoichiometric oxidants ${ }^{3}$ or directing groups to facilitate these transformations $s^{4,5}$. Related to this strategy, Stahl ${ }^{6}$ and $\mathrm{Liu}^{7}$ have recently developed mild methods to generate diarylmethanes via copper-catalyzed arylations of toluene and its derivatives with arylboronic acids (Fig. 1). Palladium-promoted toluene functionalization strategies also hold promise ${ }^{8,9}$.

We have been interested in the functionalization of very weakly acidic ( $\mathrm{p} K_{\mathrm{a}}$ up to $\sim 34$ ) benzylic C-Hs of arenes and heteroarenes via deprotonative cross-coupling processes (DCCP). Substrates for DCCP include allyl benzenes (Fig. $2 \mathrm{a})^{10}$, diarylmethanes ${ }^{11-14}$, triarylmethanes ${ }^{15}$, and benzylic sulfoxides ${ }^{16,17}$ among others. The success of DCCP relies partly on reversible deprotonation of the benzylic $\mathrm{C}-\mathrm{Hs}$ of the pronucleophile. For unactivated toluene derivatives, however, we conjectured that the high $\mathrm{p} K_{\mathrm{a}}$ values $\left(\approx 43\right.$ in $\left.\mathrm{DMSO}^{18}\right)$ of the benzylic $\mathrm{C}-\mathrm{Hs}$ were far beyond the reach of $\mathrm{MN}\left(\mathrm{SiMe}_{3}\right)_{2}$ bases $\left[\mathrm{M}=\right.$ alkali metal, $\mathrm{p} K_{\mathrm{a}} \approx 26$ for $\mathrm{HN}\left(\mathrm{SiMe}_{3}\right)_{2}$ in $\mathrm{THF}^{19}$ ]. Thus, to address this long-standing challenge, we $\mathrm{e}^{20,21}$ and others ${ }^{22}$ activated the arenes with stoichiometric transition metals by forming $\left(\eta^{6}\right.$-toluene $) \mathrm{Cr}(\mathrm{CO})_{3}$ complexes. The benzylic $\mathrm{C}-\mathrm{Hs}$ of $\left(\eta^{6}\right.$-toluene $) \mathrm{Cr}(\mathrm{CO})_{3}$ exhibit increased acidity and are reversibly deprotonated with $\mathrm{LiN}\left(\mathrm{SiMe}_{3}\right)_{2}$, enabling functionalization (Fig. 2b). The group of Matsuzaka improved upon this approach with a ruthenium-sulfonamide-based catalyst (Fig. 2c) for in situ deprotonation of toluene and dehydrative condensation with aromatic aldehydes to generate $(E)$-stilbenes ${ }^{23}$.

As a valuable complement, Schneider developed a method for functionalization of allyl benzene $\left(\mathrm{p} K_{\mathrm{a}} \approx 34^{24}\right)$ catalyzed by $\mathrm{NaN}\left(\mathrm{SiMe}_{3}\right)_{2}$ (Fig. 2d ${ }^{25}$. Benzylic functionalization of more acidic alkylazaarenes $\left(\mathrm{p} K_{\mathrm{a}} \approx 35\right.$ for 4 -methyl pyridine ${ }^{18}$ ) catalyzed by $\mathrm{KN}\left(\mathrm{SiMe}_{3}\right)_{2}$ with $\mathrm{N}, \mathrm{N}$-dimethylcinnamamide by Kobayashi and co-workers also represents an advance (Fig. 2e $)^{26,27}$. More recently, Guan reported a $\mathrm{KN}\left(\mathrm{SiMe}_{3}\right)_{2^{-}}$ catalyzed $\mathrm{C}-\mathrm{H}$ bond addition of alkylpyridines to simple styrenes (Fig. 2f ${ }^{28}$. During the revision process, Brønsted basecatalyzed benzylic $\mathrm{C}-\mathrm{H}$ bond functionalizations of toluenes and diarylmethanes were reported by Kobayashi ${ }^{29}$ and $\operatorname{Guan}^{30}$, respectively. Important early contributions involved additions of 2-methyl pyridine (Fig. 2g), and Grignard reagents (Fig. 2h) to in situ generated $\mathrm{N}$-(trimethylsilyl)imines were developed by Giles $^{31}$ and Hart ${ }^{32,33}$, respectively.

The results in Fig. $2 \mathrm{~b}-\mathrm{h}$, as well as our recent work on the use of cation- $\pi$ interactions to direct $\mathrm{C}-\mathrm{H}$ functionalization reactions ${ }^{11}$, inspired us to wonder if cation- $\pi$ interactions between toluene and earth-abundant alkali metals derived from MN $\left(\mathrm{SiMe}_{3}\right)_{2}(\mathrm{M}=\mathrm{Li}, \mathrm{Na}, \mathrm{K}, \mathrm{Cs})$ would increase the acidity of the benzylic C-Hs sufficiently to allow reversible deprotonation under relatively mild conditions. If indeed such an equilibrium could be established, which would undoubtedly lie very far to the side of toluene, would it be possible to trap the fleeting benzyl organometallic with an electrophile before rapid quenching with the conjugate acid of the base $\left[\mathrm{HN}\left(\mathrm{SiMe}_{3}\right)_{2}\right]$ ? Finally, if benzylic organometallic species could be generated from toluene and its derivatives, would it be possible to transform them into highvalue added building blocks of interest to the pharmaceutical industry?

Herein, we report a successful tandem $\mathrm{C}-\mathrm{C}$ and $\mathrm{C}-\mathrm{N}$ bondforming reaction for the one-pot chemoselective aminobenzylation of aldehydes with toluene derivatives (Fig. 2i). This method enables rapid access to a variety of 1,2-diphenylethylamine derivatives that are important building blocks in natural products and potent drugs and pharmaceuticals (NEDPA, NPDPA, lefetamine, ephenidine, MT-45, and PAO1, Fig. 2j) ${ }^{34-36}$.

\section{Results}

Preliminary reaction optimization. Initial screens were conducted with benzaldehyde (1a) in toluene (2a) with three different bases $\left[\mathrm{LiN}\left(\mathrm{SiMe}_{3}\right)_{2}, \mathrm{NaN}\left(\mathrm{SiMe}_{3}\right)_{2}\right.$, and $\left.\mathrm{KN}\left(\mathrm{SiMe}_{3}\right)_{2}\right]$ at 110 ${ }^{\circ} \mathrm{C}$ for $12 \mathrm{~h}$ (Table 1, entries $1-3, \mathrm{AY}=$ assay yield, determined by ${ }^{1} \mathrm{H}$ NMR of unpurified reaction mixtures). $\mathrm{LiN}\left(\mathrm{SiMe}_{3}\right)_{2}$ failed to give the desired product 3aa (entry 1), although it is known to react with benzaldehyde to generate aldimine ${ }^{37,38}$. This screen led to the identification of $\mathrm{NaN}\left(\mathrm{SiMe}_{3}\right)_{2}$ as a promising base, affording the product $\mathbf{3 a a}$ in $47 \%$ assay yield (entry 2). It is known that $\mathrm{K}^{+}$forms the stronger cation- $\pi$ interactions in solution in the series $\mathrm{Li}^{+}, \mathrm{Na}^{+}$, and $\mathrm{K}^{+39,40}$; however, under our conditions the potassium amide was not as successful as $\mathrm{NaN}$ $\left(\mathrm{SiMe}_{3}\right)_{2}$ (entry 3 vs. 2). This may be because $\mathrm{KN}\left(\mathrm{SiMe}_{3}\right)_{2}$ is less efficient in the formation of the aldimine ${ }^{37}$. We were also interested in examining the use of $\mathrm{CsN}\left(\mathrm{SiMe}_{3}\right)_{2}$. Unfortunately, this base is not widely available commercially like its lighter analogs ${ }^{41}$. It can be prepared, of course, but this would make the methods that require its use less attractive. O'Hara and co-workers found that $\mathrm{CsN}\left(\mathrm{SiMe}_{3}\right)_{2}$ could be generated by mixing $\mathrm{NaN}\left(\mathrm{SiMe}_{3}\right)_{2}$ with $\mathrm{CsX}(\mathrm{X}=\mathrm{Cl}, \mathrm{Br} \text {, or } \mathrm{I})^{40}$. Furthermore, combining CsN $\left(\mathrm{SiMe}_{3}\right)_{2}$ with equimolar $\mathrm{NaN}\left(\mathrm{SiMe}_{3}\right)_{2}$ led to formation of a sodium-cesium amide polymer [toluene $\left.\cdot \mathrm{CsNa}\left(\mathrm{N}\left(\mathrm{SiMe}_{3}\right)_{2}\right)_{2}\right]_{\infty}{ }^{39}$. It is noteworthy that the toluene in this structure forms a cation$\pi$ complex with the $\mathrm{Cs}^{+}[$Cs $\bullet . * t o l u e n e($ centroid $)=3.339 \AA$ ]. Such cation $-\pi$ interactions are often found in the structures of organometallic complexes ${ }^{42-44}$.

On the basis of the structures in these reports, we examined a variety of cesium salts with commercially available $\mathrm{NaN}\left(\mathrm{SiMe}_{3}\right)_{2}$ in 1:1 ratio (entries 4-13). This screen led to the identification of $\mathrm{NaN}\left(\mathrm{SiMe}_{3}\right)_{2}$ and CsTFA (TFA = trifluoroacetate) as the best combination, generating 3aa in $92 \%$ AY (entry 13). Other cesium salts either did not promote the transformation $\left(\mathrm{CsF}, \mathrm{Cs}_{2} \mathrm{CO}_{3}\right.$, $\mathrm{CsCl}, \mathrm{CsOAc}$, entries 4-7) or gave low yields of $\mathbf{3 a a}\left(\mathrm{Cs}_{2} \mathrm{SO}_{4}\right.$, $\mathrm{CsClO}_{4}$, EtCOOCs, CsBr, CsI, entries 8-12). Upon decreasing the amounts of both base and CsTFA [ 2 equiv. $\mathrm{NaN}\left(\mathrm{SiMe}_{3}\right)_{2}$ and 0.35 equiv. CsTFA], the AY of 3aa remained high (95\%, entry 15). Further lowering the CsTFA to 0.2 equiv, however, led to a slight decrease in assay yield $(89 \%$, entry 16$)$. The reactivity decreased significantly when catalytic $\mathrm{MN}\left(\mathrm{SiMe}_{3}\right)_{2}$ was used $(41 \%$, entry 17 ,

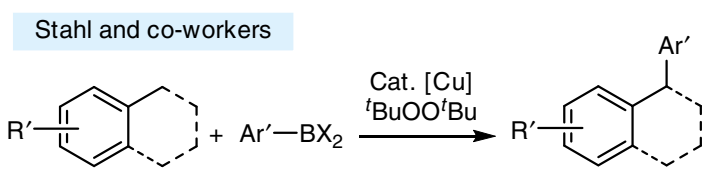

b

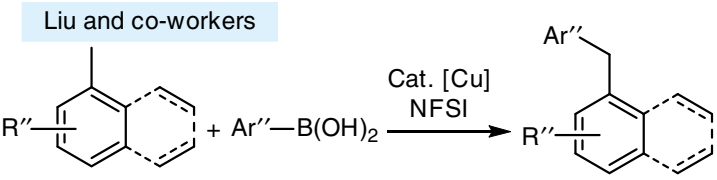

Fig. 1 Copper-catalyzed arylations of toluene derivatives. a Cu-catalyzed oxidative arylation with di-tert-butyl peroxide. b Cu-catalyzed arylation with Nfluorobenzenesulfonamide (NFSI) 
$20 \mathrm{~mol} \%)$. We wanted to determine if the combination of $\mathrm{MN}$ $\left(\mathrm{SiMe}_{3}\right)_{2}(\mathrm{M}=\mathrm{Li}, \mathrm{K})$ and CsTFA could affect the reactivity under the conditions of entry 15 , so we reexamined $\mathrm{LiN}\left(\mathrm{SiMe}_{3}\right)_{2}$ and $\mathrm{KN}\left(\mathrm{SiMe}_{3}\right)_{2}$ with CsTFA (35 mol\%). In the presence of CsTFA, the difference between $\mathrm{LiN}\left(\mathrm{SiMe}_{3}\right)_{2}$ and $\mathrm{NaN}\left(\mathrm{SiMe}_{3}\right)_{2}$ was negligible (entry 15 vs 18$)$. $\mathrm{KN}\left(\mathrm{SiMe}_{3}\right)_{2}$, however, still gave low assay yield (entry 19). We also examined the impact of temperature on the reactivity under the conditions of entry 15 . As the temperature was decreased from 110 to $30{ }^{\circ} \mathrm{C}$, the reactivity decreased slightly at 80 and $40{ }^{\circ} \mathrm{C}$ (entries 20 and 21). The reactivity decreased dramatically at $30{ }^{\circ} \mathrm{C}$ affording the desired product in $67 \%$ yield (entry 22 ). At this point, the nature of the active base and even the amount of Cs in solution remain the subject of future work. Our optimized reaction conditions for the one-pot aminobenzylation of benzaldehyde are 2 equiv. of $\mathrm{NaN}\left(\mathrm{SiMe}_{3}\right)_{2}, 1 \mathrm{~mL}$ toluene, and $35 \mathrm{~mol} \% \mathrm{CsTFA}$ at $110^{\circ} \mathrm{C}$ for $12 \mathrm{~h}$.

Scope of aldehydes. With the optimized reaction conditions in hand, we next examined the scope of aldehydes in the aminobenzylation with toluene (Table 2). In addition to the parent benzaldehyde (1a), a variety of aryl and heteroaryl aldehydes were successfully employed. Benzaldehydes bearing electron-donating groups, such as 4-t-Bu, 4-methyl, 4-methoxy, and 4- $N$, $N$-dimethylamino, exhibited very good reactivity, producing $\mathbf{3 b a}-\mathbf{3 e a}$ in
$70-88 \%$ yield. Benzaldehydes possessing halogens are also good coupling partners even at $40^{\circ} \mathrm{C}$. 4-Fluoro-, 4-chloro-, and 4bromobenzaldehydes afforded the corresponding products in $90 \%$, 98\%, and $83 \%$ yield, respectively (3fa-3ha). Likewise, 2bromo (3ia, 95\%) and 2-chloro (3ja, 98\%) benzaldehydes were very good substrates. Of course, these products could potentially be further functionalized through cross-coupling reactions. Substrates with extended $\pi$-systems, such as 1 - and 2-naphthyl aldehydes, furnished products in $92-94 \%$ yield (3ka and 3la).

In general, benzaldehyde derivatives bearing additional functional groups and heteroatoms were well tolerated. Nitriles are known to undergo nucleophilic additions with organometallic reagents ${ }^{45}$. Under our aminobenzylation conditions, however, 4cyano benzaldehyde afforded the desired product (3ma) in $70 \%$ yield with high chemoselectivity. Considering that, fluorinated compounds are extremely important in medicinal chemistry ${ }^{46}$, we examined fluorinated benzaldehydes. Both 4-trifluoromethyland 4-trifluoromethoxy benzaldehydes were excellent substrates, affording 3na and 3oa in $97 \%$ and $90 \%$ yield, respectively. Benzaldehydes containing 4-SMe, 4- $\mathrm{Ph}$, and 4-OPh groups rendered the products in $88-93 \%$ yield (3pa-3ra). The silylether containing product (3sa, 77\%) could be accessed via this protocol. Heterocyclic amines exhibit various bioactivities ${ }^{47}$. Amines containing indole, pyridine, pyrrole, and quinoline groups could be prepared with our approach, as exemplified by a

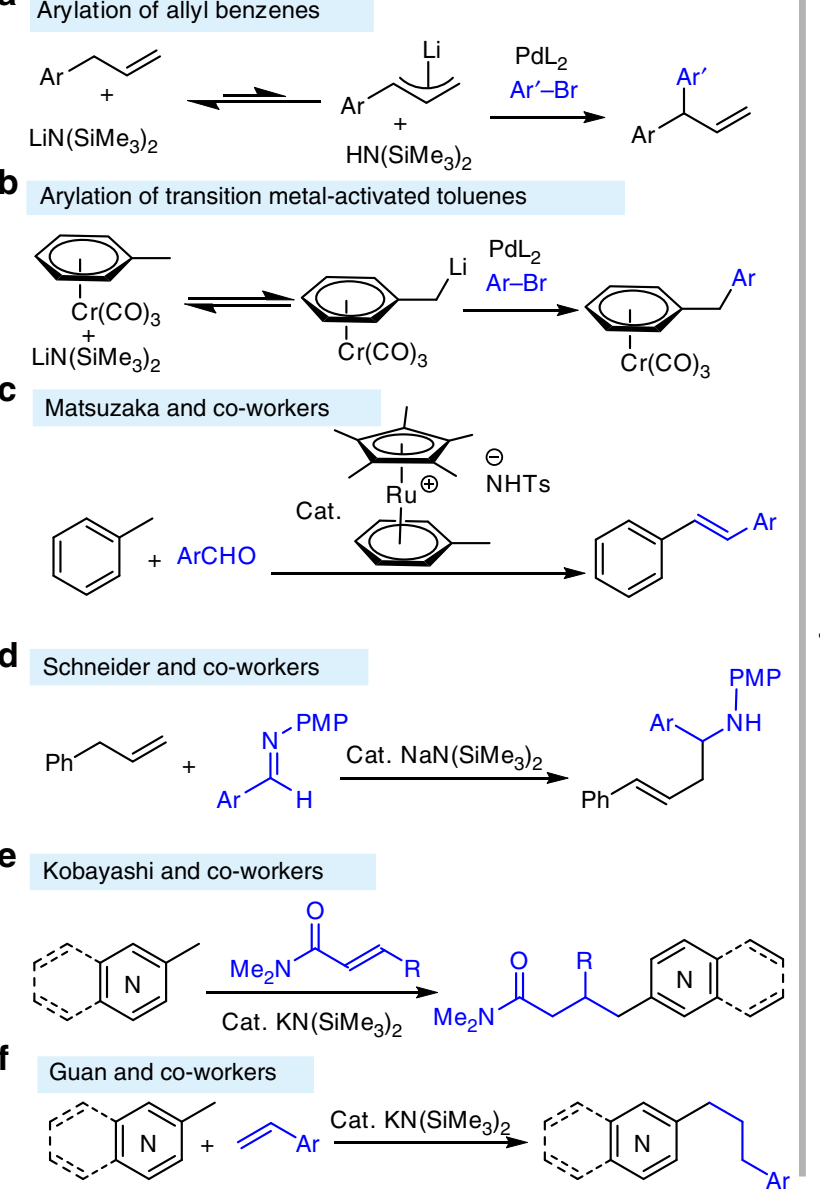

g<smiles></smiles>

h Traditional approach (from Hart and co-workers)

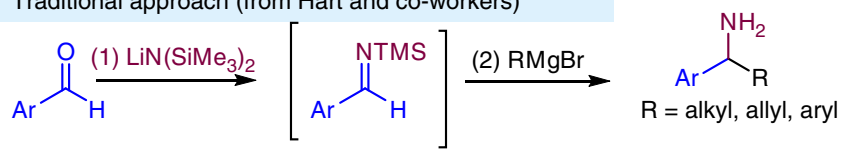

i

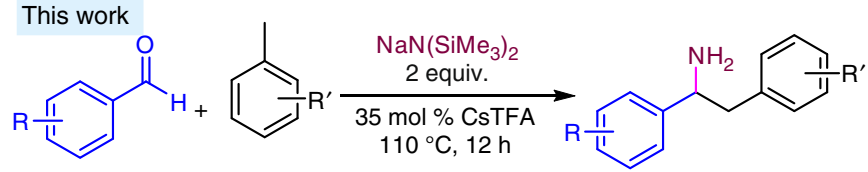

j Selected drugs and natural product containing 1,2-diphenylethylamine motifs<smiles>[R]N([B])C(Cc1ccccc1)c1ccccc1</smiles>

$\mathrm{R}^{\prime}=\mathrm{Et}, \mathrm{R}^{\prime \prime}=\mathrm{H}, \mathrm{NEDPA}$

$R^{\prime}=i \operatorname{Pr}, R^{\prime \prime}=H, N P D P A$

$\mathrm{R}^{\prime}=\mathrm{Me}, \mathrm{R}^{\prime \prime}=\mathrm{Me}$, lefetamine

$\mathrm{R}^{\prime}=\mathrm{Me}, \mathrm{R}^{\prime \prime}=\mathrm{H}$

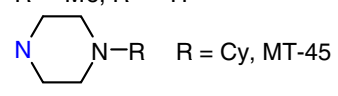

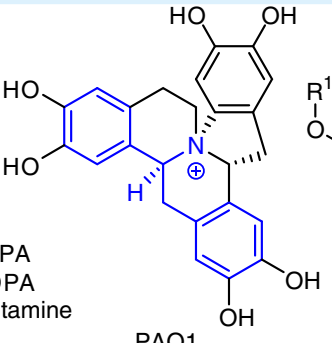<smiles>[R7]Oc1ccc2c(c1)C([R7])([R])C(c1ccccc1)N2P</smiles>

PAO1

$\mathrm{IC}_{50}=9.8 \mu \mathrm{M}$

Fig. 2 Benzylic deprotonation and related chemistry. a Arylation of allyl benzene. b Arylation of transition metal-activated toluene derivatives, c catalytic arene activation with a ruthenium complex. d Catalytic deprotonation of allyl benzene and imine addition. e Catalytic 1,4-addition reaction with alkylazaarenes by Kobayshi and co-workers. $\mathbf{f}$ Catalytic addition of benzylic C-Hs to styrenes by Guan and co-workers. $\mathbf{g}$ Related chemistry with more acidic 2-methyl pyridine. $\mathbf{h}$ Traditional approach from Hart and co-workers. i Aminobenzylation of aldehydes (this work). j 1,2-Diphenylethylamine-based drugs and natural products 
the generation of $3 \mathbf{t a}-\mathbf{3 x a}$ in $66-97 \%$ yield. Cinnamaldehyde was a competent partner under our conditions, as exemplified by the synthesis of allylic amine $3 y a$ in $56 \%$ yield.

Scope of toluene derivatives. Next, the substrate scope of toluene derivatives was examined in the aminobenzylation of benzaldehyde (1a) (Table 3). Toluenes bearing electron-donating groups, such as $4-{ }^{i} \mathrm{Pr}(\mathbf{2 b}), 4-\mathrm{OMe}(\mathbf{2 c})$, and 2 -OMe (2d), provided the corresponding products in $78 \%, 66 \%$, and $77 \%$ yield, respectively. It is noteworthy that the methyl of $p$-cymene (2b) undergoes reaction with high chemoselectivity. 4-Chlorotoluene (2e) exhibited reduced reactivity, furnishing 3ae in $66 \%$ yield at $40{ }^{\circ} \mathrm{C}$. In contrast, 2-chloro- and 2-bromotoluenes exhibited good reactivity, giving the desired products (3af and $3 \mathbf{a g}$ ) in $86 \%$ and $85 \%$ yield, respectively. For polymethyl-substituted toluenes ( $\mathbf{2 h}-$ 2k), excellent chemoselectivity was observed, affording the products (3ah-3ak) in 81-96\% yield. It is noteworthy that mesitylene was an outstanding substrate (96\% yield, 3ak). $\pi$-Extended 1methylnaphthalene was also a good substrate, affording 3al in $88 \%$ yield.

Reaction pathway. Based on the results above, we propose a reaction pathway for this one-pot aminobenzylation process. First, the $\mathrm{NaN}\left(\mathrm{SiMe}_{3}\right)_{2}$ reacts with the aldehyde to form the intermediate adduct $\mathbf{A}^{48}$, followed by an aza-Peterson olefination to afford the $N$-(trimethylsilyl)imine $\mathbf{B}$, which was not isolated but reacted directly in this one-pot process. In the presence of $\mathrm{NaN}\left(\mathrm{SiMe}_{3}\right)_{2}$ and CsTFA, the toluene derivative was reversibly deprotonated to generate an $\eta^{1}$ - or $\eta^{3}$-bound metal complex $\mathbf{C}$ and $\mathbf{C}^{\prime 49}$. The deprotonated toluene derivative then attacks the in-situ-generated aldimine $\mathbf{B}$ to give the aminobenzylated product 3 after workup (Fig. 3).

Further transformations. For a method to be useful, it must be scalable. To test the scalability of the aminobenzylation, $5 \mathrm{mmol}$ of benzaldehyde $(0.53 \mathrm{~g})$ was reacted with 2-bromotoluene $(\mathbf{2 g})$ (Fig. 4a). An $81 \%$ yield of $\mathbf{3 a g}$ was obtained. Additionally, a column-free process for direct synthesis of hydrochloride salt of 3aa was explored. Under the optimized conditions, the salt $\mathbf{3}^{\prime}$ aa was obtained in $78 \%$ yield (Fig. $4 \mathrm{~b}$ ). To further demonstrate the synthetic potential of the aminobenzylation, the product derived from 2-bromotoluene, $\mathrm{NaN}\left(\mathrm{SiMe}_{3}\right)_{2}$, and benzaldehydes 1a, 1n, $\mathbf{1 q}$, and $1 \mathbf{v}$ were readily converted into valuable 2 -aryl-substituted indoline derivatives using a Buchwald-Hartwig amination in $81-90 \%$ yield (Fig. 4 c) ${ }^{50} . N$-Substituted 2 -arylindoline derivatives are used to treat estrogen-deficiency diseases ${ }^{51}$. Furthermore, the parent 1,2-diphenylethylamine was easily converted to a diverse array of biologically active compounds (Fig. $4 \mathrm{~d})^{52}$.

\section{Discussion}

We have advanced a general method for the activation and functionalization of inexpensive toluene feedstocks at the benzylic position via a one-pot aminobenzylation of aldehydes. The reaction takes place without added transition metal catalysts and does not employ preformed main group organometallic reagents. By employing readily available benzaldehydes, commodity toluene derivatives, $\mathrm{NaN}\left(\mathrm{SiMe}_{3}\right)_{2}$, and substoichiometric Cs (TFA) a diverse array of valuable and biologically active 1,2-

Table 1 Optimization of one-pot aminobenzylation of benzaldehyde

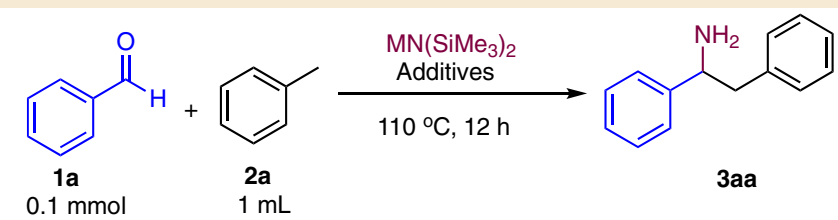

\begin{tabular}{|c|c|c|c|c|}
\hline Entry & Base & Additives & Base: additives (equiv.) & AY $(\%)^{a}$ \\
\hline 1 & $\mathrm{LiN}\left(\mathrm{SiMe}_{3}\right)_{2}$ & - & $3: 0$ & 0 \\
\hline 2 & $\mathrm{NaN}\left(\mathrm{SiMe}_{3}\right)_{2}$ & - & $3: 0$ & 47 \\
\hline 3 & $\mathrm{KN}\left(\mathrm{SiMe}_{3}\right)_{2}$ & - & $3: 0$ & 35 \\
\hline 4 & $\mathrm{NaN}\left(\mathrm{SiMe}_{3}\right)_{2}$ & $\mathrm{CsF}$ & $3: 3$ & Trace \\
\hline 5 & $\mathrm{NaN}\left(\mathrm{SiMe}_{3}\right)_{2}$ & $\mathrm{Cs}_{2} \mathrm{CO}_{3}$ & $3: 3$ & 0 \\
\hline 6 & $\mathrm{NaN}\left(\mathrm{SiMe}_{3}\right)_{2}$ & $\mathrm{CsCl}$ & $3: 3$ & 0 \\
\hline 7 & $\mathrm{NaN}\left(\mathrm{SiMe}_{3}\right)_{2}$ & $\mathrm{CsOAc}$ & $3: 3$ & Trace \\
\hline 8 & $\mathrm{NaN}\left(\mathrm{SiMe}_{3}\right)_{2}$ & $\mathrm{Cs}_{2} \mathrm{SO}_{4}$ & $3: 3$ & 20 \\
\hline 9 & $\mathrm{NaN}\left(\mathrm{SiMe}_{3}\right)_{2}$ & $\mathrm{CsClO}_{4}$ & $3: 3$ & 78 \\
\hline 10 & $\mathrm{NaN}\left(\mathrm{SiMe}_{3}\right)_{2}$ & $\mathrm{EtCO}_{2} \mathrm{Cs}$ & $3: 3$ & 17 \\
\hline 11 & $\mathrm{NaN}\left(\mathrm{SiMe}_{3}\right)_{2}$ & $\mathrm{CsBr}$ & $3: 3$ & 34 \\
\hline 12 & $\mathrm{NaN}\left(\mathrm{SiMe}_{3}\right)_{2}$ & Csl & $3: 3$ & 53 \\
\hline 13 & $\mathrm{NaN}\left(\mathrm{SiMe}_{3}\right)_{2}$ & CsTFA & $3: 3$ & 92 \\
\hline 14 & $\mathrm{NaN}\left(\mathrm{SiMe}_{3}\right)_{2}$ & CsTFA & $2: 3$ & 92 \\
\hline 15 & $\mathrm{NaN}\left(\mathrm{SiMe}_{3}\right)_{2}$ & CsTFA & $2: 0.35$ & 95 \\
\hline 16 & $\mathrm{NaN}\left(\mathrm{SiMe}_{3}\right)_{2}$ & CsTFA & $2: 0.2$ & 89 \\
\hline $17^{b}$ & $\mathrm{NaN}\left(\mathrm{SiMe}_{3}\right)_{2}$ & CsTFA & $1.2: 0.35$ & 41 \\
\hline 18 & $\mathrm{LiN}\left(\mathrm{SiMe}_{3}\right)_{2}$ & CsTFA & $2: 0.35$ & 94 \\
\hline 19 & $\mathrm{KN}\left(\mathrm{SiMe}_{3}\right)_{2}$ & CsTFA & $2: 0.35$ & 50 \\
\hline $20^{c}$ & $\mathrm{NaN}\left(\mathrm{SiMe}_{3}\right)_{2}$ & CsTFA & $2: 0.35$ & 92 \\
\hline $21^{d}$ & $\mathrm{NaN}\left(\mathrm{SiMe}_{3}\right)_{2}$ & CsTFA & $2: 0.35$ & 91 \\
\hline $22^{e}$ & $\mathrm{NaN}\left(\mathrm{SiMe}_{3}\right)_{2}$ & CsTFA & $2: 0.35$ & 67 \\
\hline
\end{tabular}


Table 2 Scope of aldehydes ${ }^{a}$
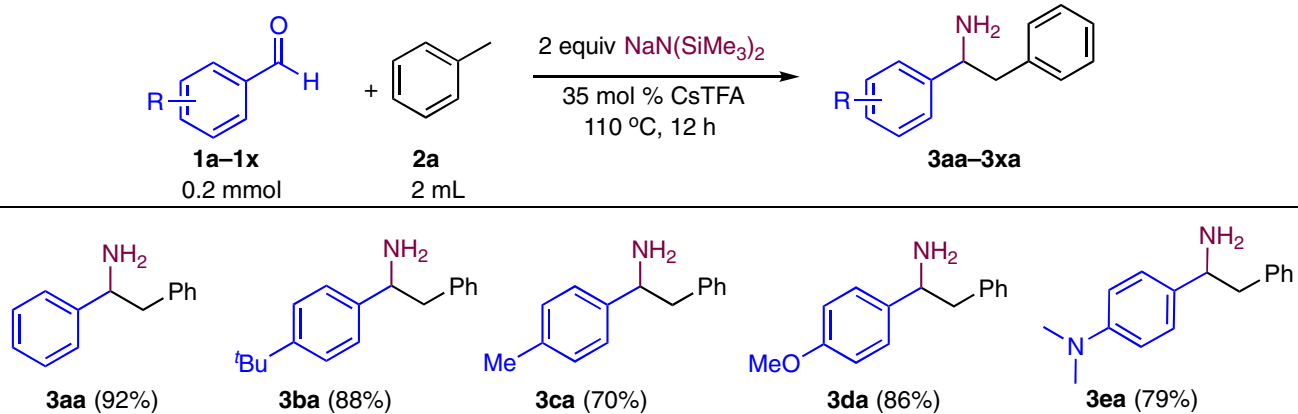<smiles>NC(Cc1ccccc1)c1ccc(F)cc1</smiles><smiles>NC(Cc1ccccc1)c1ccc(Cl)cc1</smiles>

$\mathrm{NH}_{2}$

3da (86\%)

3ea $(79 \%)$<smiles>NC(Cc1ccccc1)c1cc(C(=O)O)cc2ccccc12</smiles>

3ga $(98 \%)^{\dagger}$<smiles>PCCc1ccc(Br)cc1</smiles><smiles>NC(CPc1ccccc1)c1ccccc1Br</smiles><smiles>NC(CP)c1ccccc1Cl</smiles>

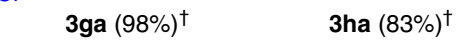
3ia $(95 \%)^{\dagger}$ $3 \mathbf{j a}(98 \%)^{\dagger}$<smiles>N#Cc1ccc(C(N)Cc2ccccc2)cc1</smiles><smiles>NC(Cc1ccccc1)c1ccc(C(F)(F)F)cc1</smiles><smiles>NC(Cc1ccccc1)c1ccc(OC(F)(F)F)cc1</smiles><smiles>COS(=O)(=O)c1ccc(C(N)C(c2ccccc2)c2ccc(C(N)c3ccc(Oc4ccc(C(N)Cc5ccccc5)cc4)cc3)cc2)cc1</smiles><smiles>CC=C(C=N)C(N)Cc1ccccc1</smiles>

3ua $(84 \%)$<smiles>NC(Cc1ccccc1)c1ccc(-n2cccc2)cc1</smiles><smiles>NC(Cc1ccccc1)c1ccc2ncccc2c1</smiles><smiles>NC(/C=C/c1ccccc1)Cc1ccccc1</smiles>

Table 3 Scope of toluene derivatives ${ }^{a}$<smiles>O=C(I)c1ccccc1</smiles>
1a $0.2 \mathrm{mmol}$

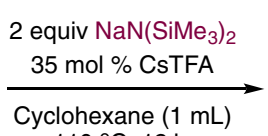

$110^{\circ} \mathrm{C}, 12 \mathrm{~h}$ 2b-I<smiles>NC(Cc1ccccc1)c1ccccc1</smiles>

3ab-3al<smiles>COc1ccc(CC(N)c2ccccc2)cc1CC(N)Cc1ccccc1OCc1ccccc1</smiles>

3ab $(78 \%)$

3ac $(66 \%) \dagger$

3ad $(77 \%)$

3ae $(66 \%) \dagger, \S$

3af $(86 \%)$

3ag (85\%)<smiles>Cc1ccccc1CC(N)c1ccccc1</smiles>

3ah $(82 \%)$<smiles>Cc1cccc(CC(N)c2ccccc2)c1</smiles>

3ai $(84 \%)$<smiles>Cc1ccc(CC(N)c2ccccc2)cc1</smiles>

3aj $(81 \%)$<smiles>Cc1cc(C)cc(CC(N)c2ccccc2)c1</smiles>

3ak (96\%)<smiles>NC(Cc1cccc2ccccc12)c1ccccc1</smiles>

3al $(88 \%) \S$ 


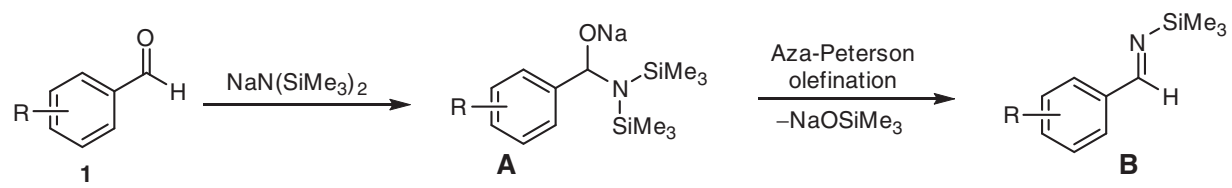

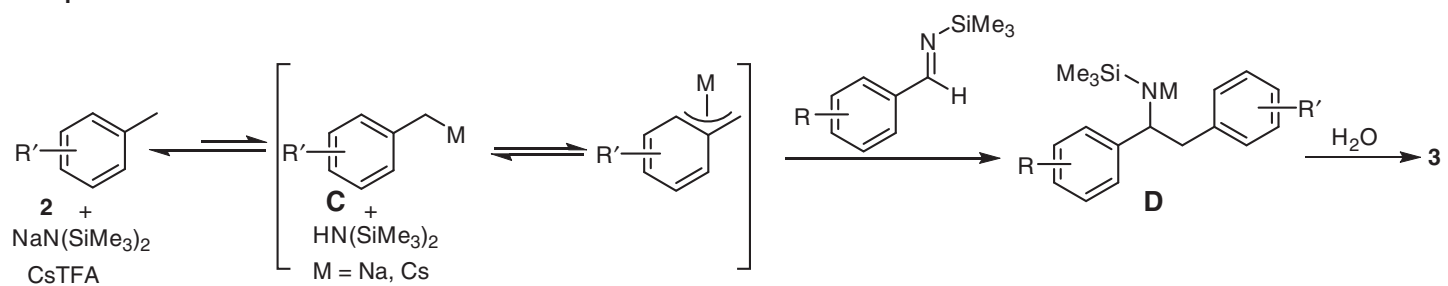

Fig. 3 Possible reaction pathway for the aminobenzylation. In situ imine formation provides aldimine B while $\mathrm{NaN}\left(\mathrm{SiMe}_{3}\right)_{2} / \mathrm{CsTFA}_{\mathrm{S}}$-mediated benzylic deprotonation generates transient organometallic $\mathbf{C}$. Intermediate $\mathbf{C}$ is trapped by $\mathbf{B}$ to furnish intermediate $\mathbf{D}$. Workup then affords the desired amine product 3

a

Grame-scale synthesis of $\mathbf{3 a g}$<smiles>[CH2+]C(=O)c1ccccc1</smiles><smiles>Cc1ccccc1Br</smiles>

1a $(5 \mathrm{mmol})$

2 g $(50 \mathrm{~mL})$

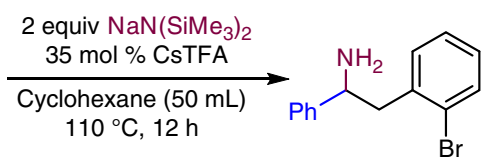
$110^{\circ} \mathrm{C}, 12 \mathrm{~h}$

3ag $81 \%(1.12 \mathrm{~g})$ b Column-free preparation of hydrochloride salt of $\mathbf{3 a a}$ Further transformation for the synthesis of 2-substituted indoline

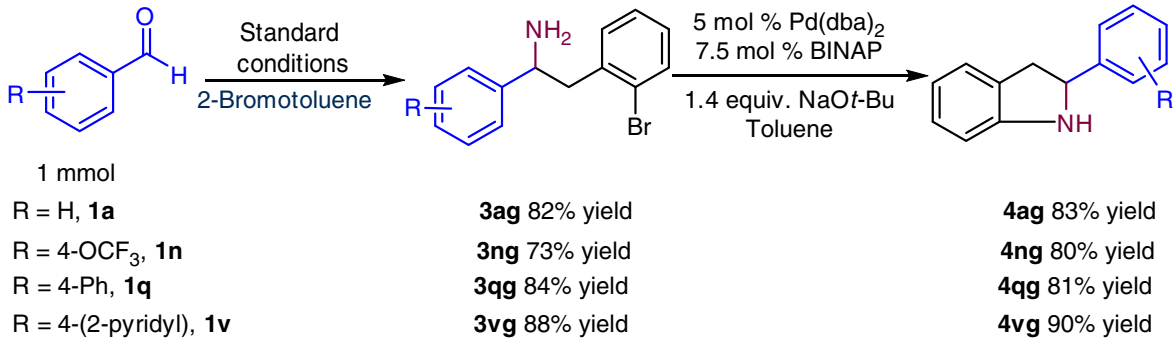

d

Synthesis of biologically active compounds

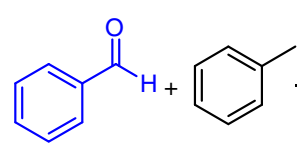

$1 \mathrm{a}(0.2 \mathrm{mmol})$

$2 a(2 \mathrm{~mL})$

(1) Standard

(2) Work up

(3) $10 \mathrm{~N} \mathrm{HCl}$<smiles>[NH3+]C(Cc1ccccc1)c1ccccc1</smiles>

3'aa $78 \%$

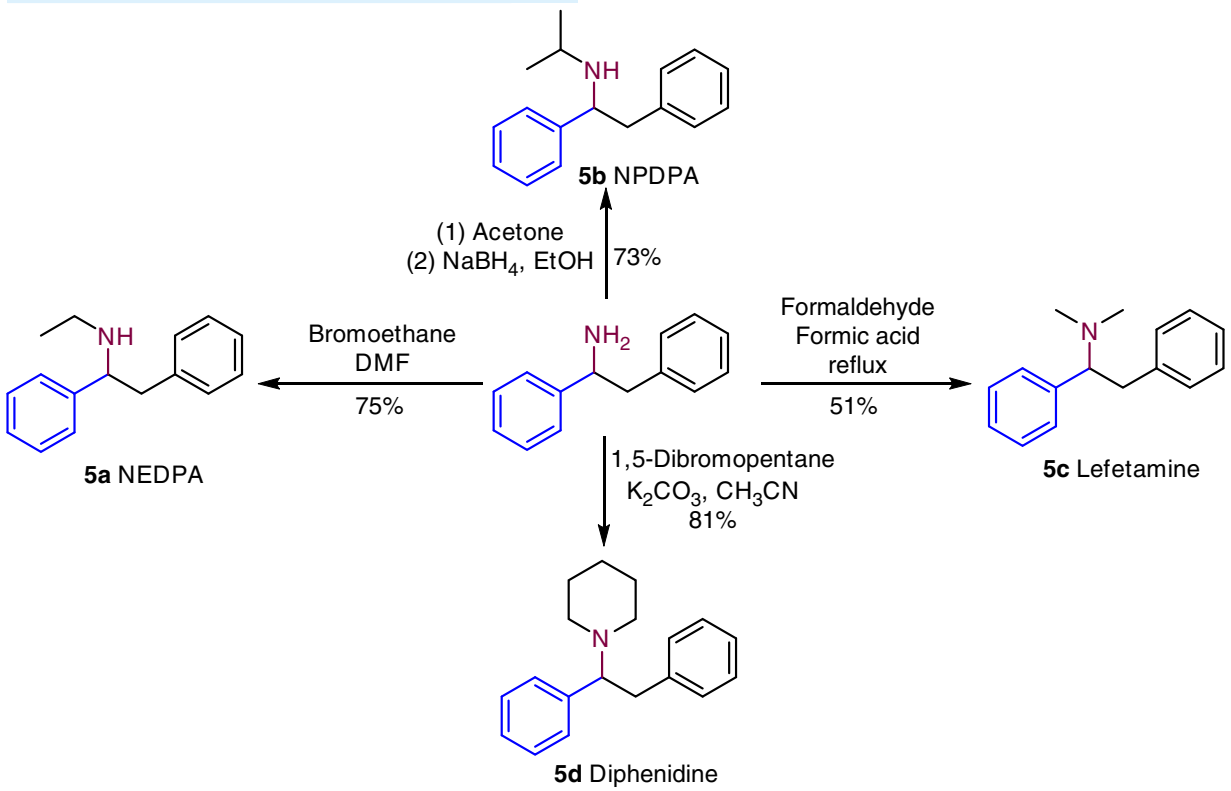

Fig. 4 Gram scale and further transformations. a Scale up of aminobenzylation. b Column-free synthesis of the hydrochloride salt of the amine product. c Synthesis of indolines via Buchwald-Hartwig amination. d Synthesis of bioactive compounds 
diarylethylamine derivatives were conveniently synthesized. The $\mathrm{N}$-alkylated analogs of our diarylethylamines are used as opioid analgesics. Additionally, this one-pot aminobenzylation exhibits remarkable chemoselectivity and excellent functional group tolerance. Suitably substituted aldehyde aminobenzylation products were readily transformed into pharmaceutically relevant 2 -arylsubstituted indoline derivatives via Buchwald-Hartwig amination.

We ascribe the success of our aminobenzylation of aldehydes to cation- $\pi$ interactions between the $\pi$-electrons of the toluene derivative and $\mathrm{Na}^{+}$and/or $\mathrm{Cs}^{+}$centers. We hypothesize that this interaction acidifies the benzylic $\mathrm{C}-\mathrm{H}$ bonds, facilitating deprotonation by moderate bases, $\mathrm{MN}\left(\mathrm{SiMe}_{3}\right)_{2}{ }^{53-57}$. Because of its simplicity and potential to produce valuable bioactive building blocks in a single step, we anticipate that this aminobenzylation reaction will find applications in medicinal chemistry.

\section{Methods}

General procedure A. To an oven-dried microwave vial equipped with a stir bar under argon atmosphere inside a glove box was added $\mathrm{NaN}\left(\mathrm{SiMe}_{3}\right)_{2}(73.2 \mathrm{mg}, 0.40$ $\mathrm{mmol})$, cesium trifluoroacetate (CsTFA) $(17.2 \mathrm{mg}, 0.07 \mathrm{mmol})$, and toluene $(2 \mathrm{~mL})$. Then, the corresponding aldehyde $(0.20 \mathrm{mmol})$ was added via syringe. The microwave vial was sealed with a cap and removed from the glove box. The reaction mixture was heated to $110^{\circ} \mathrm{C}$ in an oil bath and stirred for $12 \mathrm{~h}$. The sealed vial was cooled to room temperature, opened to air, and then five drops of water were added. The reaction mixture was passed through a short pad of silica, washed with an additional $6 \mathrm{~mL}$ of ethyl acetate $(3 \times 2 \mathrm{~mL})$, and the combined solutions were concentrated in vacuo. The crude material was loaded onto a column of silica gel for purification of the amine.

General procedure B. To an oven-dried microwave vial equipped with a stir bar under an argon atmosphere inside a glove box was added $\mathrm{NaN}\left(\mathrm{SiMe}_{3}\right)_{2}(73.2 \mathrm{mg}$, $0.40 \mathrm{mmol})$, CsTFA $(17.2 \mathrm{mg}, 0.07 \mathrm{mmol})$, the toluene derivative $(1 \mathrm{~mL})$, and cyclohexane $(1 \mathrm{~mL})$. Then, the corresponding aldehyde $(0.20 \mathrm{mmol})$ was added via syringe. The microwave vial was sealed with a cap and removed from the glove box. The reaction mixture was heated to $110^{\circ} \mathrm{C}$ in an oil bath and stirred for $12 \mathrm{~h}$. The sealed vial was cooled to room temperature, opened to air, and then five drops of water were added. The reaction mixture was passed through a short pad of silica, washed with additional $6 \mathrm{~mL}$ of ethyl acetate $(3 \times 2 \mathrm{~mL})$, and the combined solutions were concentrated in vacuo. The crude material was loaded onto a column of silica gel for purification of the amine.

Data availability. The authors declare that the data supporting the findings of this study are available within the article and its Supplementary Information files.

Received: 22 May 2018 Accepted: 17 July 2018

Published online: 22 August 2018

\section{References}

1. Bai, H. et al. Large-scale synthesis of ultrathin tungsten oxide nanowire networks: an efficient catalyst for aerobic oxidation of toluene to benzaldehyde under visible light. Nanoscale 8, 13545-13551 (2016).

2. Nandiwale, K. Y., Thakur, P. \& Bokade, V. V. Environmentally benign process for benzylation of toluene to mono-benzylated toluene over highly active and stable hierarchical zeolite catalyst. Appl. Petrochem. Res. 5, 113-119 (2015).

3. Vanjari, R. \& Singh, K. N. Utilization of methylarenes as versatile building blocks in organic synthesis. Chem. Soc. Rev. 44, 8062-8096 (2015).

4. Ma, F., Lei, M. \& Hu, L. Acetohydrazone: a transient directing group for arylation of unactivated $\mathrm{C}\left(\mathrm{sp}^{3}\right)-\mathrm{H}$ bonds. Org. Lett. 18, 2708-2711 (2016).

5. Zhang, F.-L., Hong, K., Li, T.-J., Park, H. \& Yu, J.-Q. Functionalization of C $\left(\mathrm{sp}^{3}\right)-\mathrm{H}$ bonds using a transient directing group. Science 351, 252-256 (2016).

6. Vasilopoulos, A., Zultanski, S. L. \& Stahl, S. S. Feedstocks to pharmacophores: $\mathrm{Cu}$-catalyzed oxidative arylation of inexpensive alkylarenes enabling direct access to diarylalkanes. J. Am. Chem. Soc. 139, 7705-7708 (2017).

7. Zhang, W., Chen, P. \& Liu, G. Copper-catalyzed arylation of benzylic C-H bonds with alkylarenes as the limiting reagents. J. Am. Chem. Soc. 139, 7709-7712 (2017).

8. Curto, J. M. \& Kozlowski, M. C. Chemoselective activation of $\mathrm{sp}^{3}$ vs $\mathrm{sp}^{2} \mathrm{C}-\mathrm{H}$ bonds with Pd(II). J. Am. Chem. Soc. 137, 18-21 (2015).
9. Liu, H., Shi, G., Pan, S., Jiang, Y. \& Zhang, Y. Palladium-catalyzed benzylation of carboxylic acids with toluene via benzylic C-H activation. Org. Lett. 15, 4098-4101 (2013)

10. Hussain, N., Frensch, G., Zhang, J. \& Walsh, P. J. Chemo- and regioselective C $\left(\mathrm{sp}^{3}\right)-\mathrm{H}$ arylation of unactivated allylarenes by deprotonative cross-coupling. Angew. Chem. Int. Ed. 53, 3693-3697 (2014).

11. Zhang, J. et al. Positional selectivity in C-H functionalizations of 2benzylfurans with bimetallic catalysts. J. Am. Chem. Soc. 138, 4260-4266 (2016).

12. Sha, S.-C. et al. Nickel-catalyzed allylic alkylation with diarylmethane pronucleophiles: reaction development and mechanistic insights. Angew. Chem. Int. Ed. 55, 1070-1074 (2016).

13. Zhang, J. et al. NiXantphos: a deprotonatable ligand for room-temperature palladium-catalyzed cross-couplings of aryl chlorides. J. Am. Chem. Soc. 136, 6276-6287 (2014)

14. Sha, S.-C., Zhang, J., Carroll, P. J. \& Walsh, P. J. Raising the $\mathrm{p} K_{\mathrm{a}}$ limit of soft nucleophiles in palladium-catalyzed allylic substitutions: application of diarylmethane pronucleophiles. J. Am. Chem. Soc. 135, 17602-17609 (2013)

15. Zhang, S., Kim, B.-S., Wu, C., Mao, J. \& Walsh, P. J. Palladium-catalysed synthesis of triaryl(heteroaryl)methanes. Nat. Commun. 8, 14641-14648 (2017).

16. Jia, T. et al. Palladium-catalyzed enantioselective arylation of aryl sulfenate anions: a combined experimental and computational study. J. Am. Chem. Soc. 139, 8337-8345 (2017).

17. Jia, T. et al. Diaryl sulfoxides from aryl benzyl sulfoxides: a single palladiumcatalyzed triple relay process. Angew. Chem. Int. Ed. 53, 260-264 (2014).

18. Bordwell, F. G. Equilibrium acidities in dimethyl sulfoxide solution. Acc. Chem. Res. 21, 456-463 (1988).

19. Fraser, R. R., Mansour, T. S. \& Savard, S. Acidity measurements on pyridines in tetrahydrofuran using lithiated silylamines. J. Org. Chem. 50, 3232-3234 (1985).

20. McGrew, G. I. et al. Asymmetric cross-coupling of aryl triflates to the benzylic position of benzylamines. Angew. Chem. Int. Ed. 51, 11510-11513 (2012)

21. McGrew, G. I., Temaismithi, J., Carroll, P. J. \& Walsh, P. J. Synthesis of polyarylated methanes through cross-coupling of tricarbonylchromiumactivated benzyllithiums. Angew. Chem. Int. Ed. 49, 5541-5544 (2010).

22. Kalinin, V. N., Cherepanov, Iy. A. \& K. Moiseev, S. Benzylic functionalization of ( $\eta^{6}$-alkylarene)chromium tricarbonyl complexes. J. Organomet. Chem. 536/ 537, 437-455 (1997).

23. Takemoto, $\mathrm{S}$. et al. Ruthenium-sulfonamide-catalyzed direct dehydrative condensation of benzylic C-H bonds with aromatic aldehydes. J. Am. Chem. Soc. 138, 14836-14839 (2016)

24. Bowden, K. \& Cook, R. S. Reactions in strongly basic solutions. VI. Correlation of the rates of rearrangement of weak carbon acids in aqueous methyl sulfoxide with an acidity function. Substituent and kinetic isotope effects. J. Chem. Soc. Perkin Trans. 2, 1407-1411 (1972).

25. Bao, W., Kossen, H. \& Schneider, U. Formal allylic $\mathrm{C}\left(\mathrm{sp}^{3}\right)-\mathrm{H}$ bond activation of alkenes triggered by a sodium amide. J. Am. Chem. Soc. 139, 4362-4365 (2017).

26. Suzuki, H., Igarashi, R., Yamashita, Y. \& Kobayashi, S. Catalytic direct-type 1,4-addition reactions of alkylazaarenes. Angew. Chem. Int. Ed. 56, 4520-4524 (2017).

27. Yamashita, Y. \& Kobayashi, S. Catalytic carbon-carbon bond-forming reactions of weakly acidic carbon pronucleophiles using strong Brønsted bases as catalysts. Chem. Eur. J. 24, 10-17 (2018).

28. Zhai, D.-D., Zhang, X.-Y., Liu, Y.-F., Zheng, L. \& Guan, B.-T. Potassium amide-catalyzed benzylic C-H bond addition of alkylpyridines to styrenes. Angew. Chem. Int. Ed. 57, 1650-1653 (2018).

29. Yamashita, Y., Suzuki, H., Sato, I. \& Kobayashi, S. Catalytic direct-type addition reactions of alkylarenes with imines and alkenes. Angew. Chem. Int. Ed. 57, 6896-6900 (2018).

30. Liu, Y.-F., Zhai, D.-D., Zhang, X.-Y. \& Guan, B.-T. Potassium-zincatecatalyzed benzylic C-H bond addition of diarylmethanes to styrenes. Angew. Chem. Int. Ed. 57, 8245-8249 (2018).

31. Giles, M. Process for the preparation of 1-phenyl-2-(2-pyridyl)ethanamine which does not require the use of butyl lithium. WO 2000063175 (2000).

32. Hart, D. J., Kanai, K., Thomas, D. G. \& Yang, T. K. Preparation of primary amines and 2-azetidinones via $\mathrm{N}$-(trimethylsilyl)imines. J. Org. Chem. 48, 289-294 (1983).

33. Das, M. \& O'Shea, D. F. Highly selective addition of a broad spectrum of trimethylsilane pro-nucleophiles to N-tert-butanesulfinyl imines. Chem. Eur. J. 21, 18717-18723 (2015)

34. Martin, F. et al. Alkaloids from the chinese vine gnetum montanum. J. Nat. Prod. 74, 2425-2430 (2011).

35. Wink, C. S. D., Meyer, G. M. J., Meyer, M. R. \& Maurer, H. H. Toxicokinetics of lefetamine and derived diphenylethylamine designer drugs-contribution of human cytochrome P450 isozymes to their main phase I metabolic steps. Toxicol. Lett. 238, 39-44 (2015). 
36. Natsuka, K., Nakamura, H., Negoro, T., Uno, H. \& Nishimura, H. Studies on 1-substituted 4-(1,2-diphenylethyl)piperazine derivatives and their analgesic activities. 2. Structure-activity relationships of 1-cycloalkyl-4-(1,2diphenylethyl)piperazines. J. Med. Chem. 21, 1265-1269 (1978).

37. Panunzio, M. \& Zarantonello, P. Synthesis and use of N-(trimethylsilyl) imines. Org. Process Res. Dev. 2, 49-59 (1998).

38. Posner, G. H. \& Lentz, C. M. A directing effect of neighboring aromatic groups on the regiochemistry of formation and stereochemistry of alkylation and bromination of ketone lithium enolates. Evidence for lithium-arene coordination and dramatic effect of copper(I) in controlling stereochemistry and limiting polyalkylation. J. Am. Chem. Soc. 101, 934-946 (1979).

39. Ojeda-Amador, A. I., Martinez-Martinez, A. J., Kennedy, A. R. \& O’Hara, C. T. Structural studies of cesium, lithium/cesium, and sodium/cesium bis (trimethylsilyl)amide (HMDS) complexes. Inorg. Chem. 55, 5719-5728 (2016).

40. Ojeda-Amador, A. I., Martinez-Martinez, A. J., Kennedy, A. R. \& O’Hara, C. T. Synthetic and structural studies of mixed sodium bis(trimethylsilyl)amide/ sodium halide aggregates in the presence of $\eta^{2}-N, N-, \eta^{3}-N, N, N / N, O, N-$, and $\eta^{4}-N, N, N, N$-donor ligands. Inorg. Chem. 54, 9833-9844 (2015).

41. Edelmann, F. T., Pauer, F., Wedler, M. \& Stalke, D. Preparation and structural characterization of dioxane-coordinated alkali metal bis(trimethylsilyl)amides. Inorg. Chem. 31, 4143-4146 (1992).

42. Klinkhammer, K. W., Klett, J., Xiong, Y. \& Yao, S. Homo- and heteroleptic hypersilylcuprates - valuable reagents for the synthesis of molecular compounds with a Cu-Si bond. Eur. J. Inorg. Chem. 2003, 3417-3424 (2003).

43. Andrikopoulos, P. C. et al. Synthesis, structure and theoretical studies of the hydrido inverse crown $\left.\left[\mathrm{K}_{2} \mathrm{Mg}_{2}\left(\mathrm{NiPr}_{2}\right)_{4}(\mu-\mathrm{H})_{2} \cdot \text { (toluene }\right)_{2}\right]$ : a rare example of a molecular magnesium hydride with a $\mathrm{Mg}-(\mu-\mathrm{H})_{2}-\mathrm{Mg}$ double bridge. Eur. J. Inorg. Chem. 2003, 3354-3362 (2003).

44. Gokel, G. W. The aromatic sidechains of amino acids as neutral donor groups for alkali metal cations. Chem. Commun. 3, 2847-2852 (2003).

45. Pospisil, J. \& Marko, I. E. Total synthesis of Jerangolid D. J. Am. Chem. Soc. 129, 3516-3517 (2007)

46. Purser, S., Moore, P. R., Swallow, S. \& Gouverneur, V. Fluorine in medicinal chemistry. Chem. Soc. Rev. 37, 320-330 (2008).

47. Ruiz-Castillo, P. \& Buchwald, S. L. Applications of palladium-catalyzed C-N cross-coupling reactions. Chem. Rev. 116, 12564-12649 (2016)

48. Chan, L.-H. \& Rochow, E. G. Syntheses and ultraviolet spectra of Norganosilyl ketimines. J. Organo. Chem. 9, 231-250 (1967).

49. Hoffmann, D. et al. $\eta^{3}$ and $\eta^{6}$ Bridging cations in the $N, N, N^{\prime}, N^{\prime \prime}, N^{\prime \prime}$ pentamethyldiethylenetriamine-solvated complexes of benzylpotassium and benzylrubidium: an x-ray, NMR, and MO study. J. Am. Chem. Soc. 116, 528-536 (1994).

50. Konya, K., Pajtas, D., Kiss-Szikszai, A. \& Patonay, T. Buchwald-Hartwig reactions of monohaloflavones. Eur. J. Org. Chem. 2015, 828-839 (2015).

51. Ullrich, J. W. Preparation of N-substituted indolines as estrogenic agents. WO $2000051982(2000)$

52. Wink, C. S. D., Meyer, G. M. J., Zapp, J. \& Maurer, H. H. Lefetamine, a controlled drug and pharmaceutical lead of new designer drugs: synthesis, metabolism, and detectability in urine and human liver preparations using GC-MS, LC-MSn, and LC-high resolution-MS/MS. Anal. Bioanal. Chem. 407, 1545-1557 (2015).

53. Banerjee, $\mathrm{S}$. et al. Ionic and neutral mechanisms for $\mathrm{C}-\mathrm{H}$ bond silylation of aromatic heterocycles catalyzed by potassium tert-butoxide. J. Am. Chem. Soc. 139, 6880-6887 (2017).
54. Toutov, A. A. et al. Silylation of C-H bonds in aromatic heterocycles by an earth-abundant metal catalyst. Nature 518, 80-84 (2015).

55. Pardue, D. B., Gustafson, S. J., Periana, R. A., Ess, D. H. \& Cundari, T. R. Computational study of carbon-hydrogen bond deprotonation by alkali metal superbases. Comput. Theor. Chem. 1019, 85-93 (2013).

56. Ma, J. C. \& Dougherty, D. A. The cation- $\pi$ interaction. Chem. Rev. 97, 1303-1324 (1997)

57. Kumpf, R. A. \& Dougherty, D. A. A mechanism for ion selectivity in potassium channels: computational studies of cation- $\pi$ interactions. Science 261, 1708-1710 (1993).

\section{Acknowledgements}

The authors acknowledge the start-up grant of Nanjing Tech University (3980001601 to P.J.W. and 39837112 to J.M.) and Natural Science Foundation of Jiangsu Province, China (BK20170965) for financial support. P.J.W. thanks the US National Science Foundation (CHE-1464744). The authors are grateful for financial support by SICAM Fellowship by Jiangsu National Synergetic Innovation Center for Advanced Materials. Prof. Peng Cui (Anhui Normal University), Prof. Lili Zhao (Nanjing Tech University), and Dr. Haolin Yin (Caltech University) are thanked for helpful discussions.

\section{Author contributions}

Z.W., X.X., Z.Z., and J.M. performed the experiments and analyzed the data. J.M. and P.J. W. conceived the project and wrote the manuscript. All authors discussed the results and commented on the manuscript.

\section{Additional information}

Supplementary Information accompanies this paper at https://doi.org/10.1038/s41467 018-05638-y.

Competing interests: The authors declare no competing interests.

Reprints and permission information is available online at http://npg.nature.com/ reprintsandpermissions/

Publisher's note: Springer Nature remains neutral with regard to jurisdictional claims in published maps and institutional affiliations.

Open Access This article is licensed under a Creative Commons Attribution 4.0 International License, which permits use, sharing, adaptation, distribution and reproduction in any medium or format, as long as you give appropriate credit to the original author(s) and the source, provide a link to the Creative Commons license, and indicate if changes were made. The images or other third party material in this article are included in the article's Creative Commons license, unless indicated otherwise in a credit line to the material. If material is not included in the article's Creative Commons license and your intended use is not permitted by statutory regulation or exceeds the permitted use, you will need to obtain permission directly from the copyright holder. To view a copy of this license, visit http://creativecommons.org/ licenses/by/4.0/

(C) The Author(s) 2018 